\title{
The Chicano Translation of Troy: Epic Topoi in the Novels of Rudolfo A. Anaya
}

\author{
Paul Beekman Taylor \\ University of Geneva
}

"Homo fuge! Whither should I fly?"

(Faustus II, i, 77)

"How has it come to pass that a people can hold

So long in their memories marvels of things As resplendent as the deeds that did the Trojans in bold battle?"1

The Trojan war spawned the civilizations of Europe and seeded the European story. Destroyed Troy set loose wandering tribes displaced from one homeland in search of another, just as the destruction of the fourth world, in the myths of North and Meso-America, set loose tribes in migratory waves, destined someday to rediscover one another and their ancestral home. Each of Rudolfo A. Anaya's novels in his trilogy, Bless Me, Ultima, Heart of Aztlan and Tortuga, mirrors this general pattern of displacement and migration, and each is intertextually linked to the European literary tradition which records it. The extent to which Anaya reaches to European myth and legend in his reshaping of Native American myth has not been sufficiently scanned as a central topic of Anaya criticism, which has been focused almost exclusively on his representation of indigenous materials. Anaya not only refers occasionally to classical myth in his works, but he appropriates in large measure the topoi of classical story as a means of aligning distinctive features of early European and traditional MesoAmerican culture. ${ }^{3}$ What is at stake, ultimately, is finding a proper place for the Chicano story in a Eurocentric literary economy.

The two branches of European cultural myth which are most prominent in the framework of Anaya's fiction are, first, the destruction and displacement story whose basic, but not exclusive, archetype is Homer's Odyssey, and, second, the founding myth whose archetype is Virgil's Aeneid. The two are complementary, since destruction of a nation and displacement of its inhabitants force the founding of a new home which will infuse into a new terrain what is salvaged of the older culture. 
The typical Odyssean hero is a restless wanderer, a careless destroyer and trickster whose adventures are occasions to serve personal interests, while a founder-hero like Aeneas is led to disdain selfinterests in deference to an announced destiny concerning a future nation. The purpose of the Aenean hero is single-minded and his errant wandering is an accidental straying from a straight-line course toward a new location where the cultural rituals of his lost land can be re-instituted. The Odyssean hero seems almost reluctant to get home, or to hold to it once he has returned.

In the Ulyssean mold we can see the restless, apparently aimless vaquero of the llano, hard-drinking, tale-telling, full of the pleasures he can find on the land, such as Gabriel Márez and his three older sons in Bless Me, Ultima, the sons and daughters of Clemente Chávez in Heart of Aztlan, and Tortuga in the novel of that name who, even as he is returning home, anticipates returning to the place he has just left. In the Aenean mold is the agricultural village founder epitomized in Bless Me, Ultima by the Luna priest who founds El Puerto, by Clemente Chávez, who leads his family from Guadalupe to Albuquerque in Heart of Aztlan, and most curiously by Juanito Faraway, the Indian in Tortuga who is exiled from his pueblo and in his attempt to return home loses his way only to found, inadvertently, a cultural tradition in a faraway place (TOR 78), hence his name. ${ }^{6}$

Let me begin, however, at the beginning, with Anaya's stories of foundations. Before Troy, Zeus seized the Phoenician Europa, daughter of Phoenix, and in the form of a bull carried her westward across the sea to Crete, where she gave birth to Minos and, therefore, to the great Minoan culture of the second millennium before Christ. In this story is the archetype of violence, displacement, and founding, whose nucleate emblem is the phoenix, the bird reborn out of its own ashes. An essential element of this primal myth is the engendering of a mestizo generation, for European culture is born of the union of opposite tendencies and opposing spirits of place. From Europa in a foreign land, European culture sprang, and so Zeus and Europa are mythological foreshadowings of the New World's Cortés and Malinche, ancestral parents of the Chicano.

The war of Troy was incited by a carrying across borders, or translation, of the Spartan Helen to Ilium. Helen herself is a product of a mixed union between Zeus (in the form of a swan) and Leda. To Tros, the founder of Troy, Zeus had given the Palladion, the image of Athena whose residence in Troy guarantees the city's security. Tros's grandson Laomedon had the citadel of Troy (Ilos) constructed by Poseidon, god of the sea, and Apollo, god of the sun, though he neglected to pay their wages. Between sea and sun fly Dedalus and Icarus from Minos, and sea and sun are the elements of the vaquero 
who flies over the llano (HOA 86).

Reflecting this creation story, Anaya's hero Antonio dreams of his father's plan to build a castle on a hill ( $B M U$ 23), for which his older brothers, whom Antonio conceives in Old World terms as "giants," did the construction (BMU 57,63, 175). In Heart of Aztlan, Adelita tells her daughters that when the Chávez family was still intact-that is, before the Tejanos began buying up the land and forcing the Chicano to move westward - "I remember watching the Chávez brothers walk on that llano-land of theirs. My God, you would have sworn that they were gods themselves the way they held themselves and walked upon that earth" (HOA 78). Just as Cassandra foresaw the fate of Troy, Antonio foresees in dream the burning of his castle (BMU 167), and Tortuga dreams an end of the world in the tearing loose of the mountain whose name he bears (TOR 186-87).

Troy had competing protectors. Athena, whose sign is the owl and whose virtue is wisdom, is Troy's founding goddess. Venus, whose power is love, is another guardian of Troy, for Paris, who awarded her the prize for beauty, is Priam's son, and she is the mother of Aeneas, who is drawn into the fray on the side of the Trojans. Similarly, on the llano edge of Guadalupe, in north-central New Mexico, the jefita of the Márez ranchito is Antonio's mother, but the spiritual guide for Antonio is Ultima, to whom he feels closer affinities (BMU 115). As the removal of the Palladion marks the doom of Troy, the death of Ultima's owl foreshadows the end of the Márez residence on the hill over Guadalupe.?

Typical of creation myths, the construction of Troy involves a complication which is a primary cause of its ultimate and inevitable. destruction. Betrayal is one of the causes for the wasting of creation. As Adam and Eve betrayed their contract with their Creator concerning the Tree of Knowledge, Laomedon betrays a contract with Apollo and Poseidon in the building of Troy. ${ }^{8}$ Helen's welcome and protection within the walls of Troy is another complication which accelerates Troy's course toward destruction. In the Odyssey, Ulysses's careless revelation of his identity to Polyphemos incites the wrath of Poseidon, who finds ways to delay the hero's return to Ithaca. Along the route of return, Ulysses causes, one way or another, the deaths of all his companions.

There are analogous complications, both overt and hidden, in the status quo of place and society in each of Anaya's novels. Hidden in Antonio's bloodstrain in Bless Me, Ultima is an innate incompatibility of the restless vaquero temperament of his father with the homehugging, farming mentality of his mother. The conflict of character is never resolved, and by the time Antonio becomes aware of its terrible force, it has already caused the exile of his three older brothers from 
the ranchito. Even earlier, Gabriel Márez's marriage had forced him into exile from the freedom-loving society of the llano: "The move lowered my father in the esteem of his campadres," Antonio recalls (BMU 2). A complication of far greater public consequence is revealed to him by his friend Samuel, who tells him of the doom awaiting the village of Guadalupe because of the betrayal of a covenant with the god incarnate in the Golden Carp (BMU 73-75).

More significant, however, is Antonio's own unwitting betrayal of Ultima. Just as Aeneas, perhaps out of a desire to protect the Palladion, the altar of Athena whose emblem is the owl of reason, ends by betraying it, Antonio unwittingly betrays to Tenorio the secret association of Ultima and her owl (BMU 181, 242). On the other hand, like Ulysses who kills the Cyclops, Tonio is a giant-killer, at least in the eyes of his friend, Vitamin Kid: "Toni-eeee the giant killer'...Andrew laughed. 'Why did he call you, the giant killer-' 'I don't know;' I nodded. I thought of my brothers as giants. Now two were gone" (BMU 69). Tonio is, of course, an excuse for the departure of the brothers, who see in him, during their absence, the fulfillment of their mother's dreams. Tonio is also responsible for the departure of his third brother, simply by being witness to Andrew's failure to rouse himself from his lotophagian ease in Rosie's brothel to prevent the death of Narciso. ${ }^{9}$

In the Heart of Aztlan, the initial betrayal which lies behind the first event of the story is Moisé's squandering away of the family ranch after the death of his and Clemente's father (HOA 5-6). ${ }^{10}$ Later in exile in Albuquerque, the evil which permeates the barrio and makes the first breach into family solidarity is the marijuana which floats over the city like a cloud of destruction, like the cry of la Llorona in the winds which sweep across the llano the Chávez family have left behind: "I am the spirit of your past" it cries in the sirens of the police cars (HOA 18), and it is Benjie's smoking "pot" that compels Clemente to beat one of his children for the first time (HOA 43). ${ }^{11}$ As Antonio unwittingly gives an enemy the means to destroy Ultima, Jason Chávez unwittingly contributes to his brother's broken back, for it is his confrontation with Sapo which causes the gang leader to threaten Benjie, and it is Jason's challenge to him in the railyards that causes Sapo to fire wildly, hitting Benjie by chance (HOA 198).

In Tortuga, the hero, who carries no other name than that of the mountain and the tortoise with which he is compared because of his full-body cast, arrives in the hospital for crippled children with the unexplained mystery of the cause of his accident. There is a further mystery in his wounded left hand which is never treated and which remains crippled at the end of his cure. As Antonio does, Tortuga suggests a course of action which kills his spiritual guide. In his horror 
at the suffering of the polio victims, he thinks of putting them out of their pain (TOR 118); and later, while doves cry by the Rio Grande, Tortuga insists publicly that something must be done about them. One of his hearers takes it upon himself to act (TOR 136-37,161) and throws the electrical switches. The "vegetables" die, bereft of the electrical power which permits them to breathe.

Their deaths, including that of his friend Salomón, immediately precedes Tortuga's journey away from Ismelda, to whom he pledges to return someday (TOR 195). ${ }^{12}$ Salomón's death, and Ismelda's rendering up of him, sends Tortuga back into the world alone. Ultima's death sends Antonio off on his own, and the break-up of Clemente Chávez's family is marked by the drift of his children away from him. Aztlán, like the mythic Troy, is a factory of nations. The fall of Troy propelled peoples to the margins of the known world. The victorious Greeks go back to their various homes, often ill-fit for return, and the surviving Trojans set out for new lands with remnants of their culture.

Similarly, Anaya's Clemente Chávez, forced out his homeland of the Eagle and Nopal (HOA 8) - an allusion to Tenochtitlán-must find a new home and future (HOA 8). Though his move to Albuquerque is, as he himself proclaims, a return-" "You know that the first Chávezes were from this valley" (HOA 9) - Clemente is less optimistic about the future: "I will be cast adrift, there will be no place left to return to, no home to come back to," to which the narrator adds: "It was like setting adrift on an unknown, unchartered ocean" (HOA 3).

One hears such thoughts in Aeneas as he quits Ilium for the sea: "With tears I quit my native shores and harbours, and the plains, where once was Troy. An exile, I fare forth upon the deep, with my comrades and son, and the great gods of the Penates." 13 Antonio dreams of his brothers, "driven to wander by the wild sea-blood in their veins. Shrouded in a sea-mist they walked the streets of a foreign city" (BMU 225). As Ulysses and Aeneas hear stories of the dispersal from Troy, Antonio listens to the vaquero history of the llano, sad corridos of "blood, murder and tragedy. The people were uprooted" (119). The buyer of Clemente's ranchito speaks of the others who have already drifted away to Santa $\mathrm{Fe}$, California and Albuquerque, never to return (HOA 4). Adelita would carry from Guadalupe the "spirit of the land" in "a canful of simple, good earth" (HOA 7), but Clemente fears that his bond with the land cannot be carried with him. Once in the urban barrio, his wife sees him as a "man lost in a foreign land" (HOA 78), and an older Chicano laments that "we were dispersed from our own land, our way of life was destroyed, we had to recreate our pueblos in the slum-barrios of the cities" (HOA 103).

An eloquent figure for the translation of culture from one form and place to another-though it is meant to illustrate the impossibility of 
translating an ultimate state of sin to a state of grace - is the exemplum Father Byrnes offers his young catechumens in Bless Me, Ultima to give substance to the idea of Eternity:

"Try to imagine our whole country is a mountain of sand. A mountain of sand so high that it reaches to the clouds, and so wide that it stretches from one ocean to the other.... Now suppose across the ocean there is a flat country. The ocean is very wide and it takes weeks to cross it, right. But you want to move this huge mountain of sand from here to there.... Let me tell you how you have to move that enormous mountain of sand. And it is not with a boat.... A little sparrow is going to move that mountain for you. It has to pick up only one grain of sand, fly all the way across the wide ocean, put down the grain of sand, then fly all the way back for another grain of sand. It takes the little bird weeks just to fly across the ocean, and each time it carries only one grain of sand."

"Is that how long eternity is?" Agnes asked bravely.

"No...when the little bird has moved that mountain of sand across the ocean, that is only the first day of eternity." (BMU 193-94)

There are two issues in this conventional lesson which are particularly pertinent to the Chicano context. The first is the measure of time which, in Father Arnall's retreat sermon in Joyce's Portrait of the Artist as a Young Man (from where Byrnes borrows his fable), is more radical. There, after describing several transportations of the mountain of sand, Father Arnall remarks that "not one single instant of eternity could be said to have ended," and even when the mountain rose again as many times as there are stars in the sky and drops of water in the sea, "eternity could scarcely have begun"14 (Joyce 142-43). Byrnes's "day of eternity," however, applies a natural measure where no nature exists. It is precisely nature, and particularly the sun whose rise marks the beginning of the day, with which the Chicano identifies his own being in time. "Eternity" does not pertain to Ultima's, Crispin's and Salomón's worlds.

Secondly, the Christian doctrine of irrevocable and eternal damnation is at odds with native thought, exemplified in the myth of the Golden Carp, the deity of Nature in which Antonio sees the beauty and the power he had expected from the Christian God (BMU 73-75, 104-5). Cico tells him that the Golden Carp punished sinners by transforming their natural forms (111); and "sin," Antonio learns, consists of disturbing the harmony of nature, and not, as the Church teaches him, abusing his own soul. Neither eternity nor damnation seem to fit Chicano traditional belief in the community of all things on the landscape. The incongruity of Byrnes's moral lesson with natural experience confuses Antonio until he ignores the God of the Church in favor 
of an identity with the land and its guardian forces such as the Golden Carp. ${ }^{15}$

In effect, Byrnes's fable for his catechumens is Anaya's lesson for us, a political, moral and linguistic allegory. The task of the bird is the task of the Chicano artist. Those grains of sand he must carry are not just earth, but the cultural seeds of a people, their words, story and the knowledge of things on the land. One has to draw from the old to make the new. ${ }^{16}$ The Chicano writer, like the Trojan fugitive, must fly like a bird to carry story from one place to another. The task is formidable, if not impossible.

The lesson is told in many ways. The blind bard Crispin tells Clemente the story of the dispersal of the people of Aztlán, comparing it with secular and sacred traditions of the Old World: "Think of the exodus of the people of Aztlán.... It is a story which far surpasses the wanderings of the Jews of the Bible, it is an odyssey where gods visited with men as they once did in the stories of ancient Greece.... and all of it here, on this earth, on this land of Aztlan'" (HOA 84). Earlier, Crispin tells Jason how the old priests made a guitar out of the wood of a juniper tree upon which to sing the new songs: "It was a new instrument,...passing from poet to poet, it wove the future out of things as they are...so nothing could be destroyed, so everything could be created anew" (HOA 27). He then adds his own story: "At last I moved north from Mexico in search of the land the ancients called Aztlán"'(HOA 28). That move involves a loss of one language and the appropriation of another. So the story shifts vehicle from the Nahuatl of the Aztec priests to the Spanish of the Mexicanos who drifted north after the treaty of Guadalupe Hildago in 1848, to the English of Albuquerque in mid-twentieth century. Similarly, Josefa tells Tortuga the legend of the migrations of The People along the Rio Grande valley who carried stories of their past (TOR 57), and Ultima tells Antonio of the migrations of peoples across the llano long before the Texans started to fence in the land (BMU 37). In all of these accounts is a dispersion of peoples and languages recalling the biblical story of the fragmentation of speech into many languages at Babel and the dispersal of tribes and their languages from Asia Minor throughout the Mediterranean after the fall of Troy.

Displacement is caused by inner and outer ills, hidden curses and Greek gifts, if you will, and exile is a condition prefigured by a destiny set to make new cities, which in turn will be laid waste in a perpetual cycle of emergence and destruction, not unlike the cycles of suns in American indigenous myth. The journey between destruction of the old and construction of the new is fraught with challenging dangers. There are temptations to linger on the way-temptations of the flesh which, for Ulysses and Aeneas, are represented by Calypso and Dido- 
and dangers like Scylla and Charybdis which threaten to wreck voyages. Antonio's brothers Léon and Eugenio are wrecked in their car and are rescued by the police who bring them home (BMU 172). Meanwhile, the third brother Andrew lingers behind in Guadalupe, spending his time in the seductive atmosphere of Rosie's brothel, even when his participation in urgent deeds is called for (BMU156).

Getting somewhere and managing to do what must be done are facilitated in epic process by a ritual of blood sacrifice. The shedding of the blood of a pharmakos evokes divine favor. It is an essential rite for translation, or metaforos. When Agamemnon sets sail for Troy, his sails are countered by winds sent by Artemis, who had been offended by the king. To placate her, he sacrifices his daughter Iphigenia and sails on. In one version of the story, Iphigenia is rescued by Artemis herself and carried to Taurus where she presides over sacrifices to the goddess.

The Old English word for sacrifice is blotsian, literally "to let blood." It is not surprising that the early Church in England appropriated the term for sanctification. The Modern English form of the word is bless, and to bless someone is, in effect, to rehearse symbolically Christ's spilling of blood on behalf of mankind. In Bless Me, Ultima, blessings invariably accompany spilling of blood. Lupito, bleeding to death, asks for Antonio's blessing (BMU 20). Narciso asks for Antonio's blessing as he bleeds to death under the juniper tree (BMU 162). Antonio has his own blood spilled by the church steps when Horse and the others beat him up for having blessed Florence (BMU 203-5). Finally, it is Ultima, whose owl sacrifices itself to save Antonio ( $B M U$ 245), who blesses Antonio ( $B M U$ 247). The title of the novel, then, points to both Antonio's request and Ultima's self-sacrifice.

In Tortuga, Danny sacrifices the lives of all the children in iron lungs, including Salomón, to liberate them from suffering (TOR 183). In effect, he frees them, in Salomón's own terms, "to follow the path of the sun" (TOR 172). In Heart of Aztlan, Sánchez's blood is spilled in an accident in the Santa Fe yards, and this accident ironically provides a vacant post for Clemente to fill (HOA 29).

Aeneas sacrifices Dido in the sense that she kills herself in despair after he deserts her for his destiny. That act facilitates his translation to Latium, the western goal of his voyage; and once there, he replaces Turnus and marries Lavinia. The seizing of a good portion of the new land for oneself is reflected in Clemente replacing Sánchez in the railroad yards, and in his replacement of Jesús Sena in the little barrio casa. Aeneas's new Latium is a blend of Trojan and Latin culture, and Clemente Chávez's Albuquerque barrio is a blend of vaquero and farmer, a matrix for an Anglo-Chicano mestizo culture (HOA 35, 40), though the marriage of those cultures is a stormy affair (HOA 151). ${ }^{17}$ In 
Tortuga, the Anglo cowboy Buck replaces the Navajo Geronimo in the hospital ward (TOR 70-71). Meanwhile, Jerry has died in quest of freedom.

The struggles and hardships of displacement, wandering and exile are links in the concatenation of destiny. The return of Ulysses is guided by Athena, who mediates for her hero's good among the gods, and Venus is Aeneas's advocate for her son's quest to found a city of love which will honor her. Ultima, in one of Antonio's early dreams, mediates between vaqueros and farmers over the future of Antonio by burying herself the fetal placenta in which she reads the infant's future: "I will bury the afterbirth and the cord which once linked him to eternity. Only I will know his destiny"' (BMU 6). The blind bard Crispin, the tlamantini [poet, wiseman] of the Albuquerque barrio, reads Clemente's destiny: "It is true, this Chávez will lead" (HOA 102); but not only is the object of the verb left to be understood, but Clemente's grandson is in his arms at the moment, and who the gathered friends assume is the destined leader and not the overdrinking, distraught grandfather. It is another Chávez's destiny that Salomón recognizes in Tortuga: "We don't know why we're chosen to walk the path of the sun...but we do know that it's our destiny.... Don't you see, my friend, you're the one hope that the darkness will never cover us completely" (TOR 172).

The spiritual guides of heroes who know their destiny have the power to guard them from traps in their way. Athena convinces Calypso to let Ulysses resume his way, and Venus directs Aeneas away from Dido. So Clemente is diverted from debilitating domestic squabbles by the blind singer Crispín, and Tortuga is led from self-pity by the wise Salomón and a robust physio-therapist. Ultima leads Antonio's attention and interest away from the domestic concerns of his mother. In Albuquerque, Jason feels trapped by Cindy's invitation to spend the night with her, but he breaks away as he hears the faint melody of Crispin's guitar (HOA 61). Tortuga, after he is released from the hospital, visits Ismelda, the girl he has fallen deeply in love with; but, he recalls, "I could not stay. I still had to find my way home. We both knew that. Our time would be complete when I had found my way out of the desert, and could return" (TOR 195).

As epic heroes do, Anaya's Chicano heroes visit the underworld for knowledge. The Santa Fe railroad shops are the "devil's place" (HOA 22) and "devil's shops" (HOA 17), where Jason witnesses the blood sacrifice the Chicano is forced to make with his own blood for the economic prosperity of the Anglo. It is the dark place of suffering where Clemente makes a "hellish sound" to toll the fall of his son Benjie (HOA 203). The shops are a place of hellish agony, but Clemente's knowledge of spiritual mysteries comes from two visits to La India, 
the sibylline keeper of la piedra mala [the stone of evil]. In his first visit to the bruja [witch] who lives alone in sleeplessness in the dense bosque [brush] by the river, he is invited to sell his soul for the knowledge of his destiny as leader of the barrio movement for social justice (HOA 8889). On his second visit, accompanied by Crispin as his guide, he achieves "the vision in the rock" (HOA 128-30) which guides him to the myth of his people's past and to a use of it for their future. ${ }^{18}$ Just as Tiresias in the underworld shows Ulysses the way to get home (Odyssey, XI), la piedra mala reveals Aztlán, the place "where he had begun his journey" (HOA 130).

The grove of the brujas near El Puerto in Bless Me, Ultima is a hellish place, but it is in the bedroom of Lucas, Antonio's uncle who is stricken by the black magic emanating from that place, which is the otherworldly locus of Antonio's confrontation with death. Ultima brings him there, where the body of Lucas is "a thin skeleton held together by dry skin, and on the face was written the pain of the curse" $(B M U 90)$. In this crypt-like chamber, Antonio takes within him the spirit of death (BMU93). Later, he dreams of the fires of hell (BMU16568). The labyrinthine inner wards of the hospital for crippled children in Tortuga is a living hell, within which children in iron lungs lie paralyzed, forever suffering and dying. When Tortuga is first led into them, he feels among the shrouded dead: "I could see the beds and the thin skeletons which rested on them. At first I thought they were all dead, the thin arms which rested over the single sheet that covered them were bones covered by a thin parchment of yellow skin" (TOR 38). That parchment is an elegant text of unrelenting pain. "Please God," he shouts in the darkness, "take me from this hell" (TOR 40), and his scream is his outrage against a world which would create such a hell (TOR 118). The "vegetable garden" is Salomón's home, however, and in successive visits Tortuga learns from him how to bear pain and how to ascend the path of the sun, which is love. Salomón, Crispin, la India, and Ultima, like the shades of the underworld that Ulysses and Aeneas confront, have memories which extend beyond bounds of mortality.

Clemente Chávez, despite his llano past, fits the mold of founder figures like Aeneas, but the restless wanderers in the Ulyssean mold are more common in these novels. The Chicano is an exile, first from his ancestral home in Aztlán, and then from the pueblos he has founded, each of which, as Clemente recognizes, is an image of the Tenochtitlán, or earthly paradise, he is promised as a consolation for loss. In other words, the Chicano is adrift, looking for a new home, but without knowing where it is. Gabriel Maréz has the spirit and the hope that it is in California, but lacks the money to move there, and his wife and sons have no desire to set out with him on a Californian odyssey. 
The most prominent figure of the wanderer without a goal is Clemente's son Jason, Antonio's friend back in Guadalupe, and one who has been instructed by the last survivor of the earlier Indian population displaced by the Chicanos. Jason's name evokes the epic adventurer he emulates. With the self-assurance of his Argonaut namesake, he wanders with heroic abandon through the barrio. He is the only one of his gang of vatos able to cross the border into the foreign world of the Anglo Country Club set. As the Thessalian Jason used the Colcosian woman Medea to achieve his goal, before deserting her for the Greek Creusa, Jason Chávez turns from the Anglo Cindy, who had invited Jason into her world, and pursues the Chicana Cristina.

One recalls that in the Odyssey, Book XII, Jason is given credit for being the only sailor before Ulysses to have successfully sailed between Scylla and Charybdis. Ulysses is able to save himself from the sirens, although they take the lives of others on his ship. Anaya's Jason is one able to move between the Anglo and Chicano worlds, and he escapes the sirens which are the cries of police cars searching out the drug dealers in and around the barrio. "That mother friggin' ley comes blaring down the street,"' says one of Jason's friends, "busting heads, throwing vatos in the can, and they rot there, they die there" (HOA 49). The Argonaut's Medea kills her children after Jason deserts her for another, and the cries of the legendary Llorona for the children she killed is heard by the vatos in those same police sirens. Cindy executes a kind of wild justice on Jason by accusing him of being the father of her unborn child.

The topoi of classical myth in Anaya's fiction are ubiquitous. There are the magic hunts of epic which reappear as augurs of isolation and disease in Anaya's fiction, not only in Salomón's history of himself, but particularly in short stories such as "The Silence of the Llano" and "The Place of the Swallow." The shape-shifting magic of Circe is reflected in the black magic of the Trementina sisters in Bless Me, Ultima. The temptation to idle ease which Dido offers Aeneas foreshadows the bribe to Clemente to give up his leadership. The prominent epic motif of death by drowning is almost an obsession in Anaya's novels. Ulysses and Aeneas survive near-drowning and are washed ashore where they tell their stories of wandering. Florence drowns in Bless Me, Ultima, the moon-worshipping Henry drowns in Heart of Aztlan, and Tortuga is dragged out of the pool where he has been thrown as a sort of ritual sacrifice (TOR 124). Like Melville's Ishmael, he survives to tell his story.

These topoi are meant to be recognized, for recognition engages Anaya's audience in a temporal merging of the past with present and future moments. As la India's stone does for Clemente, they force the readers's temporal consciousness out of a material framework into a 
symbolic one. What happened in Troy happens in Aztlán and what happened there happens now. There is a boustrophedon pattern in this concatenation, for going forward leads to a turning back, and the return to a new turn forward.

This pattern suggests the properties of oral performance, such as repetition, overlapping and superimposition of images. The repeated, or cyclical, patterns lend meaning to the real, just as the old tropes carry the meaning of old contexts to new ones. The many layers of texts under Anaya's stories reflect the archeological strata of Troy.

The artist, like the archeologist, is a traveller to sources. Anaya follows B. Traven to el Pozo de Mondoza, and Rosario follows Gonzalo to the village which the gods painted yellow (Silence 127, 151). A story is a treasure hidden to be unearthed and repossessed. It is a mythenlandschaft. The writer is indeed a bird that flies between both place and season. He, like Dedalus and Icarus, is bound between sun and water. The sun is Apollo and the poet, like Anaya's Salomón and Tortuga, is orphic, singing new myths out of old in order to make new orders out of the dust and ashes of the old. The poetry of the sun is the poetry of change. The juniper tree under which Ultima's owl lies, like the water tower underneath which Benjie lies and the bus seat on which Tortuga sings his song of love and return, is a perch from which story flies.

To set song aloft requires a view of the mythenlandschaft whose belvedere is memory. Antonio's, like Anaya's, reaches backward to lessons of the past. Anaya remembers the Bible, Meso-American legend, and he remembers Troy. Before him Chaucer had remembered Troy in Troilus and Criseyde, and had realized how the language of love and death changes over the span of centuries, while the fact remains the same (II, 22-42). Anaya is acutely aware of the displacement in flight of memory which is indispensable for the bardic transmission of a people's essential lore. ${ }^{19} \mathrm{He}$ has said of himself that, when writing, "I discovered I could leave my time and place and transport myself into other realms of time. But this is the work of a brujo, the task of the shaman to fly into the other realms of time or heaven or hell and rescue the souls of our characters. This is the work of the poet, to learn to fly" (A Chicano 123).

Father Byrnes's figure of the territorial translator is a swallow. Ultima's attendant is an owl, and her teacher is el hombre volador [the flying man]. In the Aeneid, Venus manifests her guidance for Aeneas in the form of doves (VI, 187-200). ${ }^{20}$ Crispin tells Clemente how Quetzalcóatl, the feathered serpent, leads his people on their migration, carrying in his flight their history with its cultural knowledge (HOA 124-25), and Quetzalcóatl is the poet-god, sun-god and god of love in Anaya's pantheon, ${ }^{21}$ not unlike the Daedalus who celebrates 
his transportation across the sea by dedicating a temple to Apollo on the Chalcidian hill (Aeneid VI, 14-19). ${ }^{22}$ Crispín says that there is an urgent need now for a flying man-an eagle as a guardian bird and spiritual guide to lead the lost Chicano (HOA 84, 86). In The Adventures of Juan Chicaspatas, Juan and Al Penco fly to Aztlán (34). Salomón tells Tortuga that words of love fly out of his mouth as butterflies: "Each carries a new story, but all the stories are bound to the same theme...life is sacred (TOR 42). Later, Tortuga dreams that he flies on the back of the mountain whose name he bears in a kind of soul journey into the realm of the stars, in an escape from a world burning in purgatorial flame (TOR 187); and the next morning he turns toward home playing Crispin's guitar. There is little of the bard in Clemente Chávez, but he recalls that his communion with the llano long ago gave him the feeling of "soaring over the landscape," a sensation confirmed by Crispin's assertion that a man "could fly like the guardian bird of the legend" (HOA 86).

The blind Crispin's Old World counterpart is Homer's Demodocus, the blind bard who sings of the fall of Troy before King Alcinous. Ulysses's continuation of the story is the archetype for the Western world's literature of first-person narration. His and Aeneas's narrative of his deeds before Dido are the archetypes for Antonio's and Tortuga's stories of self. ${ }^{23}$ We are given few clues to the occasion of Antonio's tale, but Tortuga's song as he rides in the bus taking him back home, playing his music on Crispin's guitar, is, in effect, the beginning of the story which we have just read of his experience. His song of love is a process of discovering the meaning in his experience. Even the omniscient narrator of Heart of Aztlan is, in many respects, an extension of this same voice trying vainly to make sense of the urban chaos of Albuquerque by casting a conventional lyric net over as much of it as he can.

Anaya's trilogy is, like our text of Homer's epic, a written record of oral performance. ${ }^{24}$ Anaya is as eclectic in his style as in his reach toward forms of myth which reside behind the banal shapes of experience. The oral folk traditions which permeate his particular social experience as a Chicano are flexible, and Anaya shapes them for his own purposes, since myth for Anaya is an individual matter. Each person must find, and create his or her own.

Anaya finds his in three typologies. Closest to home are the typologies of Meso-American myth, flexible in their oral transmission. The second is the scriptural story, which is Anaya's religious heritage, whose literary authority is fixed and unyielding. The third is the story from Anaya's reading in European literary culture. There is no cultural nationalism at stake in Anaya's use of any of this material, for his message is for a larger community than the barrio, the farm, or the 
llano. Like Crispin's suggestion of flight to Clemente, any one of us, Chicano or no, can take flight for Anaya's Aztlán, but we must do it on wings of Chicano fabrication.

\section{Notes}

1. Hu is paet geworden on pysse werpoede

pret ge swa monigfeald on gemynd witon,

alra tacne gehwyle swa Troiana

purh gefeoht fremedon. (Elene 643-45a)

So asks Constantine's mother of the Hebrews who feign ignorance of the location of the Holy Cross. The text is from the Anglo Saxon Poetic Records, ed. George Philip Krapp and Elliott Van Kirk Dobbie (NY: Columbia U P, 4 vols., 1931-1942), vol. 2, 83-84.

2. Bless Me, Ultima, Heart of Aztlan and Tortuga abbreviated in parentheses henceforth as $B M U, H O A$, and $T O R$, respectively. Anaya's fourth novel, Alburquerque (Albuquerque: University of New Mexico Press, 1992), appeared too late to be included in this study.

3. Enrique Lamadrid notes that "Anaya deeply penetrates the mythical conscience of the reader," and that each reader is led to reach toward his own myth (101). John $R$. Chavez recalls the European habit of interpreting native accounts of things in the New World in terms of the old, "projecting Greek myth onto a real landscape" (54-55). So Cabrillo named a river Amazon after rumors that Ciguatan was a city of women.

4. Hector Calderón sees a reflection of Circe in Rosie, the brothel owner, and something of the Cyclops in the one-eyed Tenorio. Calderon recalls Borges's divison of all story into two mythic categories: Ulyssean wandering in search of a lost island, and the sacrifice of a god (73).

5. Anaya parodies Virgil in his short comic epic, The Adventures of Juan Chicaspatas, which begins: "Arms of the women I sing." Lamadrid, "Myth as the Cognitive Process," sees the movement from pastoral to agricultural society in Bless Me, Ultima as a reflection of European historical development in the midst of which Antonio and the town of Guadalupe reside. The movement does not actually occur in the story, but one might infer it from the last view of Antonio at the end of the novel as a farmer. Northrop Frye sees such mythic structures as "salvation quests" (136).

6. Leslie Marmon Silko's Almanac of the Dead opens with a similar episode of a Laguna Indian who sleeps on the bus carrying him to exile in Phoenix, and wakes up in Tucson. The salvation quest, which implies a loss of Eden and a search for a new Eden, is reflected in all these stories, and Anaya does not hesitate to allude to scriptural history. The man who causes the migration of the Chavez family in Heart of Aztlan is Moise, but they move out of freedom and into urban slavery. I am concerned, however, with the story whose roots lie more deeply in European tradition than Christian scripture. Roberto Cantul points out several of Anaya's "coded" allusions to the Bible. Intertextual links with Scripture are everywhere, particularly in names. The evangelists are reflected in the Luna family names; and the names of Antonio's parents, Gabriel and Maria, as well as those of his uncles, Luke, Mateo and Juan, allude to Biblical figures. There are few names in Anaya's works that do not reveal something of the person who carries it, if one can read them.

7. I assume, perhaps mistakenly, that Don Jose's mention of the sale of 'Luna's 
place" and the migration of the family in the opening pages of Heart of Aztlan implies the fate of the Marez sometime between 1947 and the early fifties (HOA 4).

8. In Norse mythology, the giant Master-builder of Asgard, the home of the gods, is cheated out of his pay by Loki. See Sturlason, 66-68.

9. Another friend, Cico, calls Tonio "Antonioforous" (BMU 98), a pointed echo of "Stephaneforos" in Joyce's Portrait of the Artist as a Young Man (195). Stephen Dedalus is also an hombre volador (flying man).

10. There is a Native American mythic counterpart in the Crónica Mexicáyotl account of the two brothers in Aztlan who argue over their father's legacy. When one of them desecrates a ritual tree, the other, Mexi, leaves to found the nation of Mexico. See Pina, 23-24.

11. Marijuana is represented by Anaya in The Adventures of Juan Chicaspatas as a temptress, Maria Juana, an onomastic pointing to the double betrayal of Chicano male virility by drugs and women.

12. Joseph Campbell points out that the pattern of separation, initiation and return is the structure of the rite $d u$ passage. Such rites are, of course, "programmed" displacements, challenges to return with powers acquired while abroad (30).

13. ...cum patriae lacrimans portusque relinquo

et campos, ubi Troia fuit. feror exsul in altum cum sociis natoque, Penatibus et magnis dis.

(III, 10-12)

14. This part of the sermon has been traced to Giovanni Pietro Pinamonti's Hell Opened to Christians, to Caution Them from Entering into It (1688). The example for eternity is found earlier in The Spiritual Exercises (1548) of Ignatius Loyola, but belongs to the Elucidarium tradition of the proselytizing Church. The European philosophical thought about eternity begins with Plato's Timaeus 29a, where eternity precedes creation and time.

15. The questioning of Church doctrine is a central issue in Joyce's Portrait as well, and Anaya links Antonio to Stephen Dedalus by the name Antonioforous, which Cico uses when he invites Antonio into the circle of the Magic Carp (BMU 98), echoing Dedalus's agnomen Stephanoforos (Portrait, 182-84).

16. Anaya makes this point in a number of ways in his novels. An obvious example is the chapter headings in his novel. Bless Me, Ultima has chapter numbers in Spanish. The English chapter numbers in Heart of Aztlan are paired with glyphs from the Aztec calendar Tenalamatl. In Tortuga the chapters are numbered in arabic numerals, which can be read as either Spanish or English. Michael Pina calls the process of redoing old myth into new "transmythification," superimposing myths one upon another (45).

17. In The Adventures of Juan Chicaspatas, it is pointed out that the Spanish invader of Mexico was himself a mestizo (mix) of Goth, Visigoth, Moor, Gypsy and Jew (17).

18. The black stone Clemente must lay his hands upon recalls the black stone of Mecca, black because it absorbs the sins of those who lay their hands upon it.

19. Northrop Frye remarks that "The presence of a mythical structure in realistic fiction...poses certain technical problems for making it plausible, and the devices used in solving these problems may be given the general name of displacement" (136).

20. The dove, of course, is also a form of the Holy Ghost.

21. In Aztec myth, Huitzilopochtli is the sun-god who guides the migration of the Aztecs/Mexicos from Aztlán to their destined residence where they will find an 
eagle on a nopal devouring a serpent. In Anaya's Lord of the Dawn Quetzalcóatl is identified with both Venus and the sun (39).

22. The sun-worship which brings doom to the crew of Ulysses who slay Hyperion's oxen in Book XII of the Odyssey, and which is recalled again and again in the figure of Apollo, one of the builders of Ilium, is reflected in the sun-worship of Rufus in Heart of Aztlan, the sun adoration of the vaquero in Bless Me, Ultima, and the sun ceremony of Geronimo in Tortuga. Salomon's theology of love is solar, and the goal of his teaching is to walk the path of the sun (TOR 172-73).

23. Roberto Cantú's view in "Apolcalyse" (16), that BMU is a story told in an urban setting to an audience that has to be reminded of past llano traditions, is stimulating. One suspects that Antonio, like Melville's Ishamel in Moby Dick, is still himself restless and wandering at the time he tells the story - not necessarily the facts, as Cantú points out (17).

24. The final paragraph of Bless Me, Ultima makes this quite clear in its sudden holding still of time at the moment of the burial of Ultima's owl. The verb tenses shift from narrative past tense to future conditional: "Tomorrow, the women would...my father would...the mourners would...." Then the novel closes with "tonight."

\section{Works Cited}

Anaya, Rudolfo A. The Adventures of Juan Chicaspatas. Houston: Arte Público, 1985. . Alburquerque. Albuquerque: U of New Mexico P, 1992. Bless Me, Ultima. Berkeley: Tonatiuh Quinto Sol, 1972. . A Chicano in China. Albuquerque: $U$ of New Mexico P, 1986. . Heart of Aztlan. Albuquerque: U of New Mexico P, 1976. . Lord of the Dawn. Albuquerque: U of New Mexico P, 1987. . The Silence of the Llano. Berkeley: Tonatiuh Quinto Sol, 1982. . Tortuga. Berkeley: Editorial Justa Publications, 1979.

Anaya, Rudolfo A., and Francisco Lomeli, eds. Aztlàn: Essays on the Chicano Homeland. Albuquerque: Academia/El Norte Publications, 1979.

Calderón, Hector. "Bless Me, Ultima: A Chicano Romance of the Southwest." GonzalezT., 6499.

Campbell, Joseph. The Hero with a Thousand Faces. Princeton: Princeton U P, 1973.

Cantú, Roberto. "Apocalypse as an Ideological Construct: The Storyteller's Art in Bless Me, Ultima." Gonzalez-T. 13-63.

Chaucer, Geoffrey. "Troilus and Criseyde." The Riverside Chaucer. Ed. Larry D. Benson et al. Boston: Houghton Mifflin, 1987.

Chavez, John R. "Aztlán, Cibola, and Frontier New Spain." Anaya and Lomeli, 4971.

"Elene." Anglo-Saxon Poetic Records, II. New York: Columbia U P, 1932.

Frye, Northrop. The Anatomy of Criticism. Princeton: Princeton U P, 1957.

Gonzalez-T., Cesar A., ed. Rudolfo A. Anaya: Focus on Criticism. La Jolla, CA: Lalo P, 1990.

Homer. Odyssey. Harmondsworth: Penguin Classics, 1946.

Joyce, James. A Portrait of the Artist as a Young Man. 1916. London: Penguin, 1992.

Lamadrid, Enrique, "Myth as the Cognitive Process of Popular Culture in Rudolfo Anaya's Bless Me, Ultima: The Dialectics of Knowledge." Gonzalez-T., 100-12.

Marlowe, Christopher. The Complete Plays of Christopher Marlowe. Ed. Irving Ribner. New York: Odyssey P, 1963.

Melville, Herman. Moby Dick. 1851. New York: Library of America, 1983. 
Pina, Michael. "The Archaic, Historical and Mythicized Dimension of Aztlán." Anaya and Lomeli, 14-48.

Silko, Leslie Marmon. Almanac of the Dead. New York: Simon and Schuster, 1991. Sturlason, Snorri. The Prose Edda. Trans. Jean I. Young. Berkeley: U of California P, 1964.

Virgil. Ed. and trans. H.R. Fairclough. Cambridge: Harvard U P, 1954. 